\title{
Health Literacy - a review of research using the European Health Literacy Questionnaire (HLS-EU-Q16) in 2010-2018
}

Kompetencje zdrowotne (,health literacy") - przegląd badań z wykorzystaniem europejskiego kwestionariusza kompetencji zdrowotnych (HLS-EU-016) w latach 2010-2018

\section{Barbara Niedorys ${ }^{1}$, Agnieszka Chrzan-Rodak¹, Barbara Ślusarska²}

'PhD student at the Department of Family Medicine and Environmental Nursing, Faculty of Health Sciences, Medical University of Lublin/ Doktorantka w Zakładzie Medycyny Rodzinnej i Pielęgniarstwa Środowiskowego, Wydział Nauk o Zdrowiu, Uniwersytet Medyczny w Lublinie 2Department of Family Medicine and Environmental Nursing, Faculty of Health Sciences, Medical University of Lublin/ Zakład Medycyny Rodzinnej i Pielęgniarstwa Środowiskowego, Wydział Nauk o Zdrowiu, Uniwersytet Medyczny w Lublinie

\section{ORCID: \\ Agnieszka Chrzan-Rodak: 0000-0001-8786-4079 Barbara Ślusarska: 0000-0003-0101-9216 \\ CORRESPONDING AUTHOR/AUTOR DO KORESPONDENCJ: \\ Barbara Niedorys \\ Wydział Nauk o Zdrowiu UM w Lublinie \\ ul. Staszica 4/6, 20-250 Lublin \\ e-mail: baskaniedorys@gmail.com}

Wprowadzenie. Pojęcie Health Literacy używane jest często zamiennie jako „kompetencje zdrowotne”, „zdolność zdrowotna” lub „alfabetyzm zdrowotny". Wiąże się z umiejętnościami i motywacją ludzi do uzyskiwania i rozumienia informacji dotyczących zdrowia. W celu poprawy zrozumienia zdrowia i oceny Health Literacy w różnych populacjach opracowano wiele instrumentów do pomiaru kompetencji zdrowotnych. Wśród nich znajduje się wielowymiarowy, kompleksowy kwestionariusz HLS-EU-016, opracowany przez Konsorcjum Krajów Europejskich.

Cel pracy. Przegląd badań dotyczących kompetencji zdrowotnych (Health Literacy) z wykorzystaniem Europejskiego Kwestionariusza Kompetencji Zdrowotnych (HLS-EU-Q16) w oparciu 0 analizę literatury.

Metoda. Przegląd tematyczny, niesystematyczny literatury obejmujący lata 2010-2018. Analizie dokonanej przez autorów opracowania poddano 17 pozycji źródłowych.

Wyniki. Ogólny poziom Health Literacy był wyższy badaniach pochodzących z Europy niż w badaniach pozaeuropejskich. Niski poziom Health Literacy odnotowano u osób starszych i przewlekle chorych, imigrantów i więźniów oraz osób z niskim wykształceniem. Z analizy badań wynika, że ograniczone umiejętności zdrowotne badanych mają związek z pogorszeniem stanu funkcjonalnego i umiejętności poznawczych u osób starszych. Zaś decydującym wyznacznikiem niskiego poziomu Health Literacy wśród imigrantów i więźniów jest bezrobocie oraz niskie wykształcenie. Istotna jest więc odpowiednia edukacja zdrowotna społeczności lokalnych, która pełni kluczową rolę w poprawie społecznego poziomu świadomości zdrowotnej, a tym samym przyczynia się do długoterminowego zdrowia całej populacji.

Słowa kluczowe: health literacy, kompetencje zdrowotne, HLS EU Q16, przegląd literatury (HLS-EU-016) IN 2010-2018

Introduction. The concept of health literacy is often used as "health competence", "health ability. It involves the skills and motivation of people to obtain and understand health information. To improve health understanding and assessment of health literacy, many instruments have been developed to measure health competences in different populations. Among them there is the multidimensional, comprehensive questionnaire HLS-EU-016, developed by the Consortium of European Countries.

Aim. Review of health literacy studies using the European Health Competence Questionnaire (HLS-EU-Q16) based on literature analysis.

Method. Thematic review, unsystematic literature covering the years 2010-2018. The number of 17 source items was analyzed by the authors. 
Results. The overall level of health literacy was higher in European research than in non-European research. Low levels of health literacy were found in the elderly and chronically ill, immigrants and prisoners, as well as people with low education. The analysis of the research shows that the limited health skills of the respondents are related to the deterioration of the functional state and cognitive skills in the elderly. The decisive determinant of the low level of health literacy among immigrants and prisoners is unemployment and low level of education. Adequate health education plays a key role in improving the social level of health awareness and contributes to the long-term health of the entire population.

Key words: health literacy, health competences, HLS EU Q16, literature review

\section{INTRODUCTION}

A completely new direction in health promotion is defining and building health competences (health literacy). The first definition of health competences comes from 1998, it was created by WHO. Health literacy represents the cognitive and social skills which determine the motivation and ability of individuals to gain access to, understand and use information in ways which promote and maintain good health [1,2]. The term health literacy is often used as , health competence', ,health ability' or , health literacy'. It involves the skills and motivation of people to obtain and understand health information. This issue also includes social competences that affect communication, negotiation and health decision making. Ability to express one's own needs and concerns, develop strategies, engage in decision-making processes and take actions to meet the needs and solve problems [3].

Olejniczak proposes the following definition of the concept of health literacy: [...] a set of competences and skills in the broadly understood health, obtained through the proper use of information sources, allowing to minimize the occurrence and impact of health risk factors on the individual and the environment in which it operates, to improve and maintain good health [4]. The high level of these competences also determines a better quality of life and adequate prevention of diseases and compliance with healthy lifestyle principles among societies [5]. Shaping a high level of health literacy should be one of the basic public health challenges of the 21 st century [3]. Many instruments to measure health competences have been developed to improve health understanding and assess health literacy in different populations. Among them there is the multidimensional, comprehensive questionnaire for measuring health literacy in general populations HLS-EU-Q16, developed by the Consortium of European Countries [6-8].

\section{AIM}

To define the scope of research on health literacy using the European Health Literacy Survey Questionnaire (HLS-EU-Q16) conducted in 2010-2018, based on analysis of literature.

\section{MATERIAL AND METHODS}

Methods of analysis and criticism of literature were used. For this purpose, reviewing the literature based on the PRISMA guidelines [9]. The review was made using the database of the Main Library of the Medical University of Lublin, which searches, among others: PubMed, Scopus, Web of Science and PBL and Google scholar. As many as 118 records were found in these databases, using the keywords: "health literacy”, „health competences” and „HLS-EU-Q16" and 17 papers were included in the final analysis. The search strategy was limited to articles published in 2010-2018. In the first stage of the literature review process the articles were qualified for analysis based on their titles, resulting in 45 articles being qualified. Then, after reading the abstracts, 28 articles were rejected and 17 papers were left for analysis (Fig. 1).

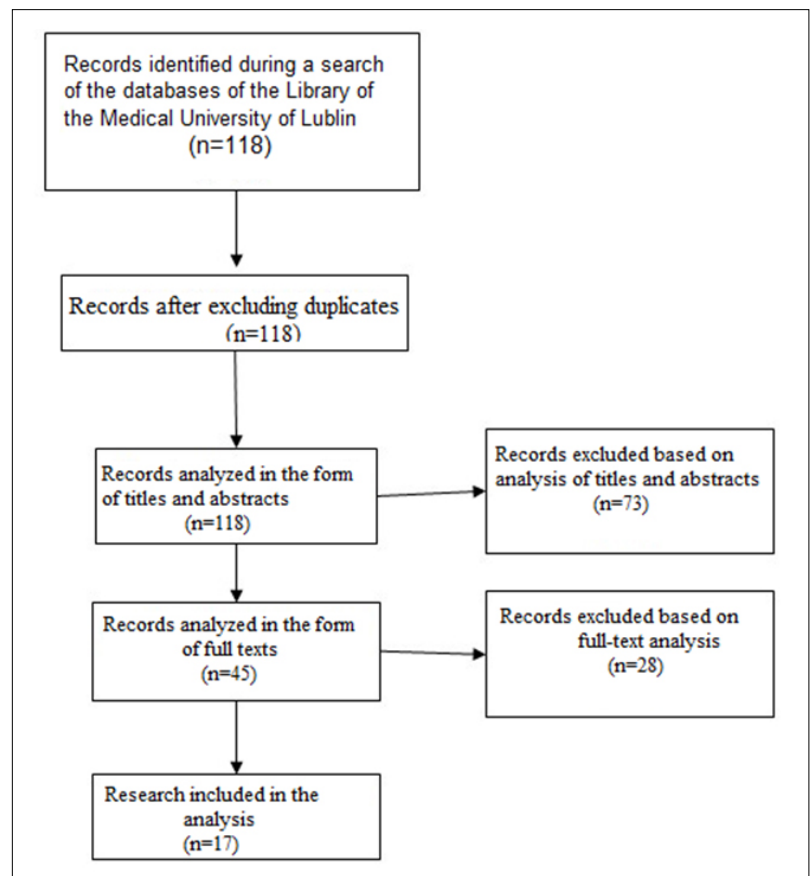

Fig 1. Scheme for qualifying articles for research analysis according to the PRISMA concept [9]

\section{Data selection}

In the publication selection process, the first author selected data on all included publications. The second author confirmed the extraction of data in the scope of publications accepted for evaluation. Data from each article were obtained in the review by two independent authors. Differences were resolved after consulting the third author of the article. The following elements were identified in the review process: sample size, data collection time, research tools, test results, hypotheses, independent variables and measurement scales, analyzes made and conclusions obtained relevant for the review. 


\section{Inclusion criteria}

The review included studies carried out in 2010-2018. The criteria determining the inclusion of works in the review were: 1) original papers, 2) papers in which the European Health Competence Questionnaire (HLS-EU-Q16) was one of the research tools, 3) papers published in Polish and English.

\section{Exclusion criteria}

Review, monographs, textbooks, training materials and information brochures were excluded in the analysis process.

Finally, 17 original papers were included in the analysis (Tab. 1). Research goals, research method and technique as well as main results were analyzed in detail.

Characteristics of the HLS EU Q16 Questionnaire: The European Health Competence Questionnaire (HLS-EU-Q16) is the short version of the HLS-EU-Q47 Questionnaire. It consists of 16 statements reflecting the perceived difficulty in accessing, understanding, assessing and applying health information in three different areas. These areas are: healthcare, disease prevention and health promotion. Each respondent expresses an opinion on a specific statement on the Likert 5-point scale (very easy, easy, difficult, very difficult, I don't know). The accumulated points obtained in the questionnaire reflect the overall assessment of health skills, categorized as follows:

- 13-16 points - sufficient health literacy level,

- 9-12 points - problematic level of Health Literacy,

- 0-8 points - inadequate health literacy level [10-13].

The questionnaire is characterized by high internal consistency and relevance. Cronbach's Alpha value in studies conducted using this questionnaire is about 0.982 [14]; 0.81 [15]; 0.71 [13]. Due to the fact that it is a short form, the questionnaire is executable in a shorter time and thus becomes more economical. It represents the same theoretical content as its longer version (HLS-EU-Q47) [16].

\section{RESULTS}

The detailed results of the review are presented in Table 1. A large part of the articles analyzed were those assessing the overall level of health competences among societies. The list includes results from Ghana [17], Poland [18], Germany [19], Egypt [20], and Israel [13]. The lowest results in the given list were obtained by the inhabitants of Egypt, where as many as $81 \%$ of the respondents had a limited level of health literacy [20]. Low results were also recorded in the society of Ghana, where as many as $62.3 \%$ of respondents presented a problematic or insufficient level of health competence [17]. In studies from Poland, $9.5 \%$ of the respondents had insufficient, and $35.8 \%$ problematic and $54.5 \%$ had sufficient or excellent health capability [18]. The highest results in terms of health competences were obtained by the societies of Israel [13] and Germany [19]. Two authors conducted a study in the group of older people $[21,22]$. Their research shows that about $50 \%$ of seniors have a sufficient level of health literacy. The level of health competences was influenced by the cognitive and physical state of the examined people and chronic diseases [21], as well as the level of education, social status and material status [22]. The research of one of the authors showed an increase in the level of health competences with the age of the examined people [22].

Research was also conducted in a group of people with different levels of education [23,24]. According to the results of a study conducted on a group of students from various fields of study, it appears that almost $31 \%$ of the total number of students have sufficient or excellent health knowledge. Medical students have a better level of health literacy [23]. One of the authors examined the feasibility of the HLS-EU-Q16 Questionnaire among people with low levels of education [24]. HLS-EU-Q16 has been shown to be a suitable instrument for determining health literacy in people with limited literacy. However, to facilitate the application and interpretation of this tool, according to the author, some questions should be simplified or clarified.

The researchers were also interested in determining the level of health literacy for refugees and immigrants $[11,12]$ and prisoners [25]. In the analyzed studies, nearly $42 \%$ of immigrants had an insufficient or problematic level of health literacy [11]. In contrast, as many as $67 \%$ of refugees had an inadequate or problematic level of health literacy [12]. Unemployment, education level [11] and low self-assessment of own health had a decisive impact on the level of health competences among this group [12]. In studies conducted on prisoners, $38 \%$ of respondents had an inappropriate level of health literacy [25].

The authors also examined the level of health competences among people with a selected disease entity, for example with cardiovascular disease [10], with breast cancer [26], and with type 2 diabetes [27]. The results of studies conducted in a group of chronically ill patients indicate that they have a lower overall level of health competence than healthy people [10]. The level of health literacy is related to the stage of their disease. In the case of women with breast cancer, respondents with low levels of health literacy showed a high level of fear of disease progression [26].

In the case of patients with type 2 diabetes, people with a high level of health literacy were more motivated to comply with dietary and physical activity recommendations [27].

The articles analyzed included those aimed at determining the psychometric properties of the HLS-EU-Q16 Questionnaire $[14,15]$. The questionnaire has been shown to be an appropriate tool for assessing health competences among people with sufficient writing and reading skills. The statements contained in the questionnaire were understandable by respondents, while the reliability factor of the tool was classified at a high level (Cronbach's Alpha> 0.982) [14]. 
Tab. 1. The scope and nature of research on health literacy using the European Health Competence Questionnaire (HLS-EU-Q16)

\begin{tabular}{|c|c|c|c|c|c|}
\hline No. & Authors & Objective of the study & \begin{tabular}{|c|}
$\begin{array}{c}\text { Number of } \\
\text { respondents }\end{array}$ \\
\end{tabular} & Method/Test tool & Main results of the study \\
\hline \multicolumn{6}{|c|}{ Health Literacy among the population of selected societies } \\
\hline 1. & $\begin{array}{l}\text { Amoah A., } \\
2018 . \\
\text { Ghana [17] }\end{array}$ & $\begin{array}{l}\text { To define the participation } \\
\text { in social life, life satisfaction } \\
\text { and Health Literacy level of } \\
\text { the inhabitants of Ghana. }\end{array}$ & $\begin{aligned} \mathrm{n} & =779 \text { persons aged } \\
& \geq 18 \text { years old }\end{aligned}$ & $\begin{array}{l}\text { Diagnostic survey } \\
\text { Questionnaire HLS-EU-Q16; } \\
\text { Life Satisfaction and } \\
\text { Wellbeing Scale (SLWS; } \\
\text { Author's Questionnaire }\end{array}$ & $\begin{array}{c}\text { Breakdown in the group: } 62.8 \% \text { of respondents } \\
\text { presented a problematic or insufficient level of health } \\
\text { competence. } \\
\text { Dependencies and relationships: Employment and } \\
\text { material situation were significantly related to the level } \\
\text { of health literacy. However, marital status and education } \\
\text { did not affect the level of health competence of the } \\
\text { respondents. }\end{array}$ \\
\hline 2. & $\begin{array}{c}\text { Duplaga M., } \\
2017 . \\
\text { Poland [18] }\end{array}$ & $\begin{array}{l}\text { Assessment of the } \\
\text { relationship between Health } \\
\text { Literacy and e-Health- } \\
\text { related competences. }\end{array}$ & $\begin{array}{c}n=1000 \text { people aged } \\
18-29 \text { years old }\end{array}$ & $\begin{array}{c}\text { Diagnostic survey } \\
\text { Questionnaire HLS-EU-Q16; } \\
\text { Scale of e-health skills } \\
\text { (eHEALS) }\end{array}$ & $\begin{array}{l}\text { Breakdown in the group: Health capacity was insufficient } \\
\text { in } 9.5 \% \text { of cases, problematic in } 35.8 \% \text {, and sufficient and } \\
\text { excellent in } 42.5 \% \text { and } 12.3 \% \text { of respondents respectively. } \\
\text { Dependencies and relationships: The level of health } \\
\text { competence is higher in high achievers in eHealth. }\end{array}$ \\
\hline 3. & $\begin{array}{c}\text { Jordan S., } \\
\text { (et al.), 2016. } \\
\text { Germany [19] }\end{array}$ & $\begin{array}{l}\text { Assessment of health } \\
\text { competences in German } \\
\text { society. }\end{array}$ & $\begin{aligned} \mathrm{n}= & 4952 \text { persons aged } \\
& \geq 18 \text { years old }\end{aligned}$ & $\begin{array}{c}\text { Diagnostic survey } \\
\text { Questionnaire HLS-EU-Q16; } \\
\text { Author's Questionnaire }\end{array}$ & $\begin{array}{l}\text { Breakdown in the group: More than half of the adults } \\
(55.8 \%) \text { have enough, } 31.9 \% \text { problematic and } 12.3 \% \\
\text { inadequate level of health literacy. } \\
\text { Dependencies and relationships: Education, age and } \\
\text { mental health status were significantly associated with the } \\
\text { level of health literacy. Gender, on the other hand, did not } \\
\text { significantly influence its level. }\end{array}$ \\
\hline 4. & $\begin{array}{l}\text { Levin-Zamir } \\
\text { D., (et al.), } \\
2016 . \\
\text { Israel [13] }\end{array}$ & $\begin{array}{l}\text { To explore the relationship } \\
\text { between health skills, health } \\
\text { behaviors, sociodemographic } \\
\text { indicators and self- } \\
\text { assessment of health in the } \\
\text { adult population in Israel. }\end{array}$ & $\begin{aligned} \mathrm{n} & =600 \text { persons aged } \\
& \geq 18 \text { years old }\end{aligned}$ & $\begin{array}{c}\text { Diagnostic survey } \\
\text { Questionnaire HLS-EU-Q16; } \\
\text { Author's Questionnaire }\end{array}$ & $\begin{array}{l}\text { Breakdown in the group: More than } 31 \% \text { of respondents } \\
\text { had insufficient or problematic health skills and } 69 \% \text { had } \\
\text { sufficient health knowledge. } \\
\text { Dependencies and relationships: The health literacy } \\
\text { level is influenced by the age, education and income of the } \\
\text { respondent. }\end{array}$ \\
\hline 5. & $\begin{array}{c}\text { Almaleh R., } \\
\text { (et al.), 2017, } \\
\text { Egypt [20] }\end{array}$ & $\begin{array}{l}\text { Measuring health skills and } \\
\text { to investigate the factors } \\
\text { associated with inadequate } \\
\text { Health Literacy levels. }\end{array}$ & $\begin{array}{l}\mathrm{n}=805 \text { patients of the } \\
\text { outpatient clinic of the } \\
\text { University Hospital } \\
\text { EL-Demerdash, aged } \\
15-85 \text { years old }\end{array}$ & $\begin{array}{l}\text { Diagnostic survey } \\
\text { Questionnaire HLS-EU-Q16; } \\
\text { Functional skills scale (S-FHL } \\
\text { scale) }\end{array}$ & $\begin{array}{c}\text { Breakdown in the group: } 81 \% \text { of respondents had } \\
\text { limited knowledge of health; } 34.3 \% \text { insufficient; } 46.7 \% \\
\text { problematic; and only } 18.9 \% \text { had a sufficient level of health } \\
\text { literacy. } \\
\text { Dependencies and relationships: Men, people with } \\
\text { a low level of education and patients with a low level of } \\
\text { functional efficiency were more likely to be exposed to an } \\
\text { insufficient level of health literacy. }\end{array}$ \\
\hline \multicolumn{6}{|c|}{ Health literacy among the elderly } \\
\hline 6. & $\begin{array}{c}\text { Eronen J. } \\
\text { (et al.), 2018. } \\
\text { Finland [21] }\end{array}$ & $\begin{array}{l}\text { Assessment of Health } \\
\text { Literacy among the elderly. }\end{array}$ & $\begin{array}{c}n=292 \text { persons aged } 75 \\
\text { years old }\end{array}$ & $\begin{array}{c}\text { Diagnostic survey } \\
\text { Questionnaire HLS-EU-016; } \\
\text { Author's Questionnaire }\end{array}$ & $\begin{array}{l}\text { Breakdown in the group: } 4.8 \% \text { of the participants had } \\
\text { insufficient, } 31.5 \% \text { problematic, } 51.4 \% \text { sufficient and } 12.3 \% \\
\text { excellent health literacy. } \\
\text { Dependencies and relationships: Better knowledge of } \\
\text { health was associated with better cognitive status, fewer } \\
\text { depressive symptoms and chronic diseases, more mobility } \\
\text { and better physical condition. }\end{array}$ \\
\hline 7. & $\begin{array}{c}\text { Tiller D., } \\
\text { (et al.), 2015. } \\
\text { Germany [22] }\end{array}$ & $\begin{array}{l}\text { Determine the Health } \\
\text { Literacy level of older people. }\end{array}$ & $\begin{array}{l}n=1117 \text { persons } \\
\text { aged } 55-91 \text { years old }\end{array}$ & $\begin{array}{c}\text { Diagnostic survey } \\
\text { Questionnaire HLS-EU-Q16 }\end{array}$ & $\begin{array}{l}\text { Breakdown in the group: Of all the respondents, } 4 \% \\
\text { showed insufficient, } 23 \% \text { problematic, } 50 \% \text { sufficient and } \\
23 \% \text { excellent knowledge of health literacy. } \\
\text { Dependencies and relationships: The level of health } \\
\text { literacy is positively influenced by a higher level of } \\
\text { education, material status and a higher self-esteem of the } \\
\text { social position. The increase in health competence with the } \\
\text { age of the examined persons was also shown. }\end{array}$ \\
\hline \multicolumn{6}{|c|}{ Health literacy among people with different levels of education } \\
\hline 8. & $\begin{array}{c}\text { Reick S., } \\
\text { (et al.), 2018. } \\
\text { Germany [23] }\end{array}$ & $\begin{array}{l}\text { Assessment of health } \\
\text { competence among } \\
\text { students. }\end{array}$ & $\begin{aligned} \mathrm{n} & =203 \text { students aged } \\
& \geq 19 \text { years old }\end{aligned}$ & $\begin{array}{c}\text { Diagnostic survey } \\
\text { Questionnaire HLS-EU-Q16 }\end{array}$ & $\begin{array}{l}\text { Breakdown in the group: } 30.7 \% \text { of students have } \\
\text { sufficient or excellent knowledge of health. } \\
\text { Dependencies and relationships: A better level of health } \\
\text { competence was found in medical students. }\end{array}$ \\
\hline 9. & $\begin{array}{c}\text { Storms H., } \\
\text { (et al.), 2017. } \\
\text { Belgium [24] }\end{array}$ & $\begin{array}{l}\text { Study on the feasibility of } \\
\text { HLSEU-Q16 in the human } \\
\text { opulation with little literacy }\end{array}$ & $\begin{array}{l}\mathrm{n}=13 \text { people aged } 18- \\
70, \text { with low education } \\
\text { and income }\end{array}$ & $\begin{array}{c}\text { Diagnostic survey } \\
\text { Questionnaire HLS-EU-Q16 }\end{array}$ & $\begin{array}{l}\text { Questions about "disease prevention" or "evaluation of } \\
\text { information" were often reported as incomprehensible. The } \\
\text { HLS-EU-016 is an appropriate instrument for determining } \\
\text { HL for people with limited literacy skills. However, in order } \\
\text { to facilitate the use and interpretation of the tool, some } \\
\text { questions should be simplified or clarified. }\end{array}$ \\
\hline
\end{tabular}


Barbara Niedorys, Agnieszka Chrzan-Rodak, Barbara Ślusarska

Tab. $1 \mathrm{~cd}$. The scope and nature of research on health literacy using the European Health Competence Questionnaire (HLS-EU-Q16)

\begin{tabular}{|c|c|c|c|c|c|}
\hline No. & Authors & Objective of the study & $\begin{array}{l}\text { Number of } \\
\text { respondents }\end{array}$ & Method/Test tool & Main results of the study \\
\hline \multicolumn{6}{|c|}{ Health literacy among refugees and prisoners } \\
\hline 10. & $\begin{array}{c}\text { Abellan C., } \\
\text { (et al.), } 2018 . \\
\text { Switzerland } \\
\text { [25] }\end{array}$ & $\begin{array}{l}\text { Determine the Health } \\
\text { Literacy level of the prisoners } \\
\text { in the canton of Vaud. }\end{array}$ & $\mathrm{n}=50$ prisoners & $\begin{array}{l}\text { Diagnostic survey } \\
\text { Questionnaire HLS-EU-Q16 }\end{array}$ & $\begin{array}{l}\text { Breakdown in the group: } 38 \% \text { of respondents had an } \\
\text { inadequate Health Literacy level. }\end{array}$ \\
\hline 11. & $\begin{array}{l}\text { Gele A. A., } \\
\text { (et al.), 2016. } \\
\text { Oslo [11] }\end{array}$ & $\begin{array}{l}\text { Assessment of the Health } \\
\text { Literacy level among Somali } \\
\text { migrant women in Oslo }\end{array}$ & $\begin{array}{l}\mathrm{n}=302 \text { Somali women } \\
\text { aged } \geq 25 \text { years old }\end{array}$ & $\begin{array}{l}\text { Diagnostic survey } \\
\text { Questionnaire HLS-EU-016; } \\
\text { Author's Questionnaire }\end{array}$ & $\begin{array}{c}\text { Breakdown in the group: } 41.8 \% \text { of the survey } \\
\text { participants had insufficient or problematic general health } \\
\text { knowledge. Only } 28 \% \text { of the sample had sufficient or } \\
\text { excellent health literacy. } \\
\text { Dependencies and relationships: Unemployed and } \\
\text { poorly educated women had a lower health literacy level. }\end{array}$ \\
\hline 12. & $\begin{array}{l}\text { Wangdahl J., } \\
\text { (et al.), 2018. } \\
\text { Sweden [12] }\end{array}$ & $\begin{array}{l}\text { Survey of health } \\
\text { competences among } \\
\text { refugees in Sweden. }\end{array}$ & $\begin{array}{l}\mathrm{n}=513 \text { Arabic, Dari } \\
\text { and Somali speaking } \\
\text { refugees aged } \geq 18 \\
\text { years old }\end{array}$ & $\begin{array}{l}\text { Diagnostic survey } \\
\text { Questionnaire HLS-EU-016; } \\
\text { Author's Questionnaire }\end{array}$ & $\begin{array}{c}\text { Breakdown in the group: } 67 \% \text { of respondents had } \\
\text { inadequate or problematic level of health literacy. } 41 \% \text { of } \\
\text { the respondents assessed their health condition as average. } \\
\text { Dependencies and relationships: Individuals with } \\
\text { worse self-esteem of their own health condition have a } \\
\text { significantly lower level of health competence. }\end{array}$ \\
\hline \multicolumn{6}{|c|}{ Health literacy among people with a selected disease unit } \\
\hline 13. & $\begin{array}{l}\text { Diederichs C., } \\
\text { (et al.), } 2018 . \\
\text { Germany } \\
{[10]}\end{array}$ & $\begin{array}{c}\text { Assessment of Health } \\
\text { Literacy in women and men } \\
\text { with cardiovascular disease. }\end{array}$ & $\begin{aligned} \mathrm{n}= & 13577 \text { persons aged } \\
& \geq 40 \text { years old }\end{aligned}$ & $\begin{array}{l}\text { Diagnostic survey } \\
\text { Questionnaire HLS-EU-Q16 }\end{array}$ & $\begin{array}{l}\text { Breakdown in the group: The problematic level of health } \\
\text { competence was found in } 41.8 \% \text { of men and } 46.7 \% \text { of } \\
\text { women with cardiovascular disease and } 33.6 \% \text { of men and } \\
33.4 \text { women without disease. } \\
\text { Dependencies and relationships: Low health literacy } \\
\text { was more common in people with cardiovascular diseases. }\end{array}$ \\
\hline 14. & $\begin{array}{l}\text { Halbach S. M., } \\
\text { (et al.), 2016. } \\
\text { Germany [26] }\end{array}$ & $\begin{array}{c}\text { To determine the Health } \\
\text { Literacy level in women with } \\
\text { newly diagnosed breast } \\
\text { cancer. }\end{array}$ & $\begin{aligned} \mathrm{n}= & 1359 \text { patients aged } \\
& \geq 65 \text { years old }\end{aligned}$ & $\begin{array}{l}\text { Diagnostic survey } \\
\text { Questionnaire HLS-EU-016; } \\
\text { Fear of cancer progression } \\
\text { questionnaire (FoP-Q) }\end{array}$ & $\begin{array}{l}\text { Breakdown in the group: } 47 \% \text { of patients had a limited } \\
\text { health literacy level. } \\
\text { Dependencies and relationships: Women with higher } \\
\text { levels of fear of cancer progression had lower levels of } \\
\text { health competence. }\end{array}$ \\
\hline 15. & $\begin{array}{c}\text { Juul L., } \\
\text { (et al.), 2018. } \\
\text { Denmark [27] }\end{array}$ & $\begin{array}{l}\text { To study the relationship } \\
\text { between the Health Literacy } \\
\text { level and diet and physical } \\
\text { activity, and motivation in } \\
\text { people with type } 2 \text { diabetes. }\end{array}$ & $\begin{array}{l}\mathrm{n}=194 \text { persons with } \\
\text { type Il diabetes } \\
\quad \text { mellitus. } \\
\text { Average age } 65 \text { years } \\
\quad( \pm 10)\end{array}$ & $\begin{array}{l}\text { Diagnostic survey } \\
\text { Questionnaire for measuring } \\
\text { selfservice activities in } \\
\text { diabetes SDSCA; Scale of } \\
\text { selfregulation of treatment } \\
\text { in diabetes (TSRQ); } \\
\text { Questionnaire HLS-EU-Q16; } \\
\end{array}$ & $\begin{array}{l}\text { Breakdown in the group: } 11 \% \text { of the respondents had } \\
\text { insufficient, 27\%problematic and } 63 \% \text { sufficient Health } \\
\text { Literacy level. } \\
\text { Dependencies and relationships: People with a higher } \\
\text { level of health literacy are more motivated to follow dietary } \\
\text { guidelines and physical activity. }\end{array}$ \\
\hline \multicolumn{6}{|c|}{ Assessment of psychometric properties Questionnaire HLS-EU-Q16 } \\
\hline 16. & $\begin{array}{c}\text { Nolasco A., } \\
\text { (et al.), } 2018 . \\
\text { Spain } \\
{[14]}\end{array}$ & \begin{tabular}{|} 
Assessment of understanding \\
and psychometric properties \\
of the HLSEU-Q16 \\
questionnaire
\end{tabular} & $\begin{array}{l}n=5485 \text { persons } \\
\text { aged } \geq 15 \text { years old }\end{array}$ & $\begin{array}{c}\text { Diagnostic survey } \\
\text { Questionnaire HLS-EU-Q16 }\end{array}$ & $\begin{array}{l}\text { The survey revealed high values of understanding of the } \\
\text { statements made in the questionnaire by the respondents. } \\
\text { Alpha Cronbach was } 0.982 \text {. The understanding coefficient } \\
\text { of the questionnaire was related to the education of the } \\
\text { respondents. }\end{array}$ \\
\hline 17. & $\begin{array}{l}\text { Rouquette A., } \\
\text { (et al.), 2018. } \\
\text { France [15] }\end{array}$ & $\begin{array}{c}\text { Validation of the HLS-EU-Q16 } \\
\text { Questionnaire. Assessment of } \\
\text { the influence of gender, age } \\
\text { and education on the level of } \\
\text { health competence. }\end{array}$ & $\begin{array}{l}\mathrm{n}=317 \text { Primary Care } \\
\text { Patients aged } \geq 18 \\
\text { years old }\end{array}$ & $\begin{array}{l}\text { Diagnostic survey } \\
\text { Questionnaire HLS-EU-Q16 }\end{array}$ & $\begin{array}{l}\text { According to the authors, HLS-EU- } 016 \text { has acceptable } \\
\text { psychometric properties. Its use is recommended for } \\
\text { measuring health literacy in populations of with sufficient } \\
\text { reading skills to distinguish between people with low and } \\
\text { medium literacy. } \\
\text { Breakdown in the group: } 8 \% \text { of the respondents had } \\
\text { inadequate, } 33 \% \text { problematic, } 58 \% \text { adequate health } \\
\text { literacy level. } \\
\text { Dependencies and relationships: It has been shown that } \\
\text { gender, age and education influence the scope of health } \\
\text { competence. }\end{array}$ \\
\hline
\end{tabular}




\section{DISCUSSION}

This article presents a review of the literature using the HLS-EU-Q16 Questionnaire from 2010-2018. This is the period in which health competence research was becoming increasingly important for public health and healthcare around the world. The issue of health competences began to be of interest at the end of the 20th century, while a broad development of research on this topic took place after 2010, when Sorensen et al. [7] conducted a European study on health competences among selected European countries. The aim of the project was to consolidate the position of health competences in Europe, by contributing to the further development of the concept of ",health competences", showing its manifestations in various European regions and cultures and discussing its impact in the social and political dimension, as well as documenting how the idea of health literacy is implemented in various national contexts [28].

HLS-EU research has generated great interest not only in Europe but also around the world. In the analyzed material, apart from research conducted in Europe, there are also works from other parts of the world such as Ghana (Africa) [17], Israel (Asia) [13] and Egypt [20]. The authors focused on assessing the level of health literacy among these societies and determining factors related to the level of health competences in these countries. The lowest level of health literacy was represented by the inhabitants of Ghana, where nearly $63 \%$ of the respondents had a problematic or insufficient level of health literacy. Low level of health literacy was more common in African women and was associated with the material status of the surveyed people. According to Amoah et al., this situation was caused by the poor economic situation of the state, limited educational opportunities among the Ghanaian community, and a patriarchal social structure that puts the needs of men over the needs of women [17]. Similar results were obtained by Levin Zamir, examining the Israeli community [13]. Almaleh et al. [20] present slightly different factors shaping the level of health competences. In the studies of these authors, conducted on outpatient clinic patients in Egypt, the largest factor shaping health literacy is gender (men have lower health literacy than women), functional fitness and level of education [20]. European studies had a higher overall level of health literacy than non-European studies. Jordan et al. [19] conducting surveys in the German community did not note any significant gender impact on the level of health literacy. According to the author, the most important determinants of health competences are education, age and mental health. In his research, over half of the respondents (55.8\%) had a sufficient level of health literacy [19]. Finding the reasons for the disproportion in health literacy levels, the research results from European and non-European countries include better grounding of projects on the development and acquisition of health competences in Europe than in other parts of the world. The results of HLS-EU have become the basis for the creation of many international strategic documents and strategic records regarding Health literacy in documents, among others, European Parliament and European Union. This is to continually improve health knowledge and make health literacy a priority in the European politics. To this end, an article was developed and disseminated among interest groups operating in the European Union community, entitled: Making health literacy a priority in $E U$ policy [29]. Health skills are also very important for older people. They allow the prevention of disability and reduce the demand for long-term care of this group. They affect the course of the process of self-management of chronic disease (recognition of symptoms, ability to take intervention measures at the time of exacerbation of the disease, compliance with medical recommendations and many others) [30]. Limited health skills cause deterioration of the functional state and cognitive skills [31]. In addition, the low level of health literacy increases the risk of frequent emergency hospitalizations and the risk of premature death [30]. That is why determining the level of health competences among the elderly is so important. In the available material, two authors [21-22] conducted studies on people of geriatric age using HLS-EU-Q16. Studies by Eronen et al. [21] show that better knowledge of health in seniors was associated with better cognitive status, fewer depressive symptoms and chronic diseases, greater mobility and better physical condition.

Global migration and immigration trends have created new challenges in the provision of healthcare due to communication, cultural differences and the health skills of migrants [32]. This explains the great interest of researchers in determining the level of health literacy among the influx of people. An analysis of available studies shows that the level of health literacy in refugees and immigrants is lower. The research of Gele et al. [11], who assessed health competences among Somali immigrants staying in Oslo, shows that the decisive determinant of the low level of health literacy among immigrants is unemployment and low education. To reduce disparities in health competences, many programs have been created to promote health literacy among migrants and refugees. An example of such an initiative was the Week of Migrant Education, organized by the Electronic Platform for Adult Education in Europe (EPALE), operating within the European Commission. The purpose of this initiative was to raise awareness about the key role of health education in the integration of migrants and refugees across Europe [33].

The relationship between health literacy and the individual's state of health is unquestioned. It is even believed that a low level of health competence is a stronger indicator of health than age, income or level of education. The above thesis is confirmed by reports from the analyzed studies conducted among chronically ill patients [10,26-27]. Diederichs et al. [10], conducting research on people with cardiovascular disease, found that low levels of health literacy occur more frequently in cardiologically ill patients than in healthy individuals. Juul et al. [27] obtained similar results in their studies. They found that people with type II diabetes with a higher level of health competence have better motivation to adhere to nutritional recommendations and principles of physical activity than people with low health literacy. According to Mirczak [30], 
the consequence of the low level of health competence among chronically ill people is lack of knowledge about the disease and tendency to negative health behaviors.

The analyzed material included articles assessing the psychometric properties of the HLS EU Q16 Questionnaire [14-15]. According to the authors, the tool has acceptable psychometric properties. Its use is recommended for measuring health literacy in populations with sufficient reading skills to distinguish people with low to medium levels of health competence [15]. In the case of people with low literacy, HLS EU Q16 has been shown to be an appropriate instrument for determining health literacy, but to facilitate the application and interpretation of the tool, some questions should be simplified or clarified [24]. The questionnaire is a short, adequate and important instrument for measuring the level of knowledge of health issues among the population and its use is recommended to detect the needs related to the management of health information [14].

\section{CONCLUSIONS}

In the analysis of the literature review using the HLS EU Q16 Questionnaire, 31,558 people from 13 countries were examined. The respondents were between 15 and 91 years old. Based on the analyzed material, the following conclusions were found:

1. There are clear disparities in the level of health literacy among European and non-European societies.

2. There is a better grounding in Europe for projects on the development and acquisition of health competences than in other parts of the world.

3. Lower levels of health literacy occur in the elderly, the chronically ill, with lower education and among immigrants.

4. Global migration trends have contributed to the development of new challenges in the provision of care and health education for the incoming population.

5. The HLS-EU-Q16 questionnaire is a suitable tool for assessing the level of health literacy among different populations.

\section{Kompetencje zdrowotne (,health literacy") - przegląd badań z wykorzystaniem europejskiego kwestionariusza kompetencji zdrowotnych (HLS-EU-Q16) w latach 2010-2018}

\section{WPROWADZENIE}

Zupełnie nowym kierunkiem działań w promocji zdrowia jest określanie i budowanie kompetencji zdrowotnych (Health Literacy). Pierwsza definicja kompetencji zdrowotnych pochodzi z 1998r, została stworzona przez WHO. Według niej Health Literacy to umiejętności poznawcze i społeczne, które determinuja motywację i zdolność osób do uzyskania dostępu, rozumienia $i$ wykorzystywania informacji w sposób, który promuje i utrzymuje dobre zdrowie $[1,2]$. Pojęcie Health Literacy używane często zamiennie jako „kompetencje zdrowotne”, „zdolność zdrowotna” lub „alfabetyzm zdrowotny”. Wiąże się z umiejętnościami i motywacją ludzi do uzyskiwania i rozumienia informacji dotyczących zdrowia. Zagadnienie to obejmuje również kompetencje społeczne, mające wpływ na komunikację, negocjacje oraz podejmowanie decyzji dotyczących zdrowia. Zdolność wyrażania własnych potrzeb i obaw, opracowywania strategii, angażowania się w procesy decyzyjne oraz podejmowania działań w celu zaspokojenia potrzeb i rozwiązywania problemów [3]. Olejniczak proponuje następującą definicję pojęcia Health Literacy: [...] zbiór kompetencji i umiejętności, $w$ zakresie szeroko rozumianego zdrowia, pozyskanych na drodze właściwego wykorzystania źródeł informacji, pozwalający na minimalizowanie występowania i wpływu czynników ryzyka zdrowotnego na jednostke i środowisko, w którym funkcjonuje, $w$ celu poprawy i utrzymania dobrego stanu zdrowia [4]. Wysoki poziom tych kompetencji decyduje również o lepszej jakości życia oraz odpowiedniej profilaktyce chorób wśród społeczeństw a także dotyczy świadomego wyboru i przestrzegania zasad zdrowego stylu życia [5]. Zatem kształtowanie wysokiego poziomu Health Literacy powinno być jednym z podstawowych wyzwań zdrowia publicznego XXI wieku [3]. W celu poprawy zrozumienia zdrowia i oceny Health Literacy w różnych populacjach opracowano wiele instrumentów do pomiaru kompetencji zdrowotnych. Wśród nich znajduje się wielowymiarowy, kompleksowy kwestionariusz do pomiaru alfabetyzmu zdrowotnego w populacjach ogólnych HLS-EU-Q16, opracowany przez Konsorcjum Krajów Europejskich [6-8].

\section{CEL PRACY}

Określenie zakresu badań dotyczących kompetencji zdrowotnych (Health Literacy) z wykorzystaniem Europejskiego Kwestionariusza Kompetencji Zdrowotnych (European Health Literacy Survey Questionnaire - HLS-EU-Q16), przeprowadzonych w latach 2010-2018, w oparciu $\mathrm{o}$ analizę literatury.

\section{MATERIAŁ I METODY}

Zastosowano metodę analizy i krytyki piśmiennictwa. W tym celu przeprowadzono przegląd piśmiennictwa w oparciu o wytyczne PRISMA [9]. Przeglądu dokonano z wykorzystaniem multiwyszukiwarki Biblioteki Głównej 
Uniwersytetu Medycznego w Lublinie, która przeszukuje między innymi takie bazy jak: PubMed, Scopus, Web of Science oraz PBL oraz wyszukiwarki Google scholar. W wyżej wymienionych bazach, wykorzystując słowa kluczowe: „Health Literacy”, „kompetencje zdrowotne”, „alfabetyzacja zdrowotna” oraz „HLS-EU-Q16” odnaleziono łącznie 118 rekordów, zaś do ostatecznej analizy włączono 17 prac. Strategia poszukiwania była ograniczona do artykułów opublikowanych w latach 2010-2018. W procesie przeglądu piśmiennictwa, w pierwszym etapie dokonano kwalifikacji prac do analizy na podstawie ich tytułów, w wyniku czego zakwalifikowano 45 artykułów. Następnie po przeczytaniu streszczeń odrzucono 28 artykułów, a pozostawiono 17 prac (Ryc. 1).

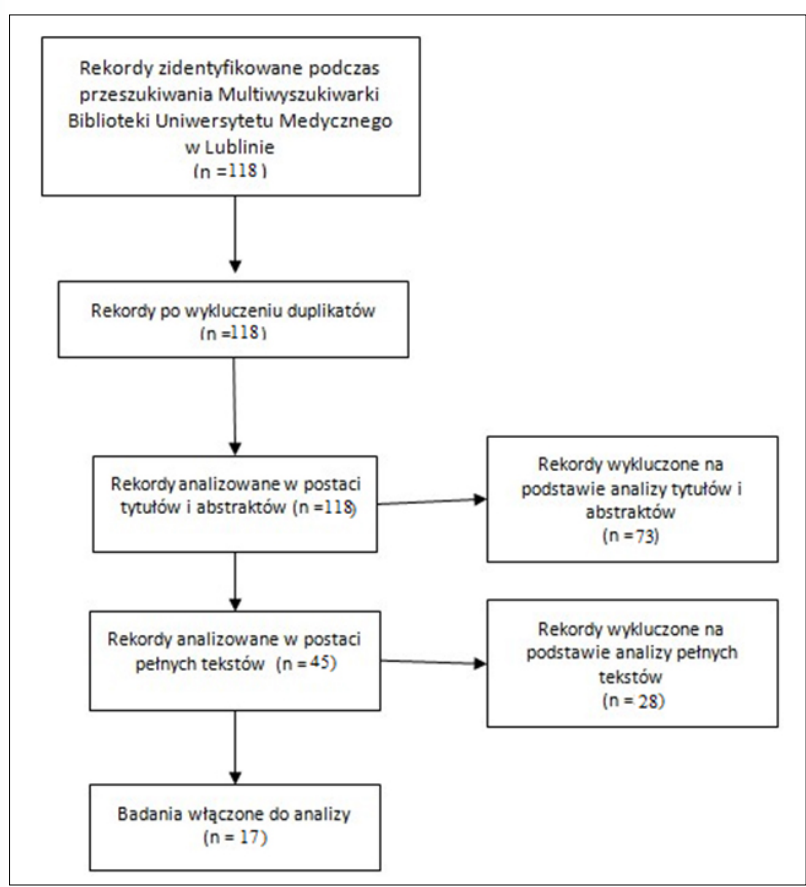

Ryc 1. Schemat kwalifikowania artykułów do analizy badawczej wg koncepcji PRISMA [9]

\section{Selekcja danych}

W procesie selekcji publikacji pierwszy autor przeprowadził dobór danych na wszystkich włączonych publikacjach. Drugi autor potwierdził ekstrakcję danych w zakresie przyjętych do oceny publikacji. Dane z każdego artykułu zostały uzyskane w przeglądzie przez dwóch niezależnych autorów. Różnice były rozstrzygane po zasięgnięciu opinii trzeciego autora artykułu. W procesie przeglądu wyodrębniono następujące elementy: wielkość próby, okres zbierania danych, narzędzia badawcze, wyniki badania, hipotezy, zmienne niezależne, zależne i skale pomiaru, dokonane analizy oraz uzyskane wnioski mające znaczenie dla przeglądu.

\section{Kryteria włączenia}

Przegląd obejmował badania przeprowadzone w latach 2010-2018. Kryteria decydujące o włączeniu prac do przeglądu były następujące: 1) prace oryginalne, 2) prace, w których jednym z narzędzi badawczych był Europejski Kwestionariusz Kompetencji Zdrowotnych (HLS-EU-Q16), 3) prace publikowane $w$ języku polskim $i$ angielskim.

\section{Kryteria wyłączenia}

$\mathrm{W}$ procesie analizy wyłączone zostały prace poglądowe, monografie, podręczniki, materiały szkoleniowe oraz broszury informacyjne.

Ostatecznie przedmiotem analizy objęto 17 prac oryginalnych [Tabela 1]. Szczegółowo przeanalizowano cele badawcze, metodę i technikę badań oraz główne wyniki.

\section{Charakterystyka Kwestionariusza HLS EU Q16}

Europejski Kwestionariusz Kompetencji zdrowotnych (HLS-EU-Q16) jest wersją skróconą Kwestionariusza HLS-EU-Q47. Składa się z 16 stwierdzeń odzwierciedlających postrzeganą trudność w dostępie, zrozumieniu, ocenie i zastosowaniu informacji na temat zdrowia $\mathrm{w}$ trzech różnych obszarach. Obszary te to: opieka zdrowotna, zapobieganie chorobom i promocja zdrowia. Każdy respondent wyraża opinię na temat konkretnego stwierdzenia w 5-punktowej skali Likerta (bardzo łatwe, łatwe, trudne, bardzo trudne, nie wiem). Zsumowane punkty uzyskane w kwestionariuszu odzwierciedlają ogólną ocenę umiejętności zdrowotnych, skategoryzowaną następująco:

13-16 punktów - wystarczający poziom Health Literacy, 9-12 punktów - problematyczny poziom Health Literacy,

0-8 punktów - nieodpowiedni poziom Health Literacy [10-13].

Kwestionariusz charakteryzuje się wysoką wewnętrzną spójnością i trafnością. Wartość Alfa Cronbacha w badaniach przeprowadzonych przy pomocy tego kwestionariusza wynosi około 0,982 [14] 0,81 [15]; 0,71 [13]. Ze względu na to, że jest to skrócona forma, kwestionariusz jest wykonywalny w krótszym czasie i przez to staje się bardziej ekonomiczny. Reprezentuje ten sam zasób treści teoretycznych co jego dłuższa wersja (HLS-EU-Q47) [16].

\section{WYNIKI}

Szczegółowe wyniki dokonanego przeglądu przedstawia Tabela 1. Wśród analizowanych artykułów sporą część stanowily prace, $\mathrm{w}$ których oceniano ogólny poziom kompetencji zdrowotnych wśród badanych społeczeństw. W zestawieniu znalazły się wyniki z Ghany [17], Polski [18], Niemiec [19], Egiptu [20], oraz Izraela [13]. Najniższe wyniki w podanym zestawieniu uzyskali mieszkańcy Egiptu, gdzie aż $81 \%$ badanych osób posiadało ograniczony poziom Health Literacy [20]. Niskie wyniki odnotowano również w społeczeństwie Ghany, gdzie aż $62,3 \%$ respondentów prezentowało problematyczny lub niewystarczający poziom kompetencji zdrowotnych [17]. W badaniach pochodzących z Polski, 9,5\% badanych posiadało niewystarczającą, zaś 35,8\% problematyczną a 54,5\% wystarczającą lub doskonałą zdolność zdrowotną [18]. Najwyższe wyniki w zakresie kompetencji zdrowotnych uzyskały społeczeństwa Izreala [13] oraz Niemiec [19].

Dwóch autorów przeprowadziło badania w grupie osób starszych [21,22]. Z wyników ich badań wynika że około $50 \%$ seniorów posiada dostateczny poziom Health Literacy. Na poziom kompetencji zdrowotnych wpływ miał 
Barbara Niedorys, Agnieszka Chrzan-Rodak, Barbara Ślusarska

Tab. 1. Zakres i charakter badań dotyczących kompetencji zdrowotnych (Health Literacy) z wykorzystaniem Europejskiego Kwestionariusza Kompetencji Zdrowotnych (HLS-EU-Q16)

\begin{tabular}{|c|c|c|c|c|c|}
\hline Lp. & Autorzy & Cel pracy & Liczba badanych & $\begin{array}{c}\text { Metoda/Narzędzie } \\
\text { badawcze }\end{array}$ & Główne wyniki badań \\
\hline \multicolumn{6}{|c|}{ Health Literacy wśród populacji wybranych społeczeństw } \\
\hline 1. & $\begin{array}{l}\text { Amoah A., } \\
2018 . \\
\text { Ghana [17] }\end{array}$ & $\begin{array}{l}\text { Określenie udziału w życiu } \\
\text { społecznym, satysfakcji } \\
\text { z życia i poziomu Health } \\
\text { Literacy wśród mieszkańców } \\
\text { Ghany. }\end{array}$ & $\begin{array}{c}\mathrm{n}=779 \text { osób w wieku } \\
\quad \geq 18 \text { lat }\end{array}$ & $\begin{array}{l}\text { Sondaż diagnostyczny/ } \\
\text { Kwestionariusz HLS-EU-Q16; } \\
\text { Skala satysfakcji z życia } \\
\text { i dobrego samopoczucia } \\
\text { (SLWS); Autorski } \\
\text { Kwestionariusz ankiety }\end{array}$ & $\begin{array}{l}\text { Rozkład w grupie: } 62,8 \% \text { respondentów prezentowało } \\
\text { problematyczny lub niewystarczający poziom kompetencji } \\
\text { zdrowotnych. } \\
\text { Zależności i związki: Zatrudnienie oraz sytuacja materialna } \\
\text { znacząco wiązały się z poziomem Health Literacy. Natomiast } \\
\text { stan cywilny i wykształcenie nie miało wpływu na poziom } \\
\text { kompetencji zdrowotnych badanych osób. }\end{array}$ \\
\hline 2. & $\begin{array}{l}\text { Duplaga M., } \\
2017 . \\
\text { Polska [18] }\end{array}$ & $\begin{array}{l}\text { Ocena związku pomiędzy } \\
\text { Health Literacy a } \\
\text { kompetencjami związanymi } \\
\text { z e-zdrowiem. }\end{array}$ & $\begin{array}{c}\mathrm{n}=1000 \text { osób w wieku } \\
18-29 \text { lat }\end{array}$ & $\begin{array}{c}\text { Sondaż diagnostyczny/ } \\
\text { Kwestionariusz HLS-EU-Q16; } \\
\text { Skala umiejętności e-zdrowia } \\
\text { (eHEALS) }\end{array}$ & $\begin{array}{c}\text { Rozkład w grupie: Zdolność zdrowotna była } \\
\text { niewystarczająca w 9,5\% przypadków, problematyczna w } \\
35,8 \% \text {, zaś wystarczająca i doskonała odpowiednio u 42,5\% } \\
\text { i 12,3\% respondentów. } \\
\text { Zależności i związki: Poziom kompetencji zdrowotnych } \\
\text { jest wyższy u osób z wysokimi wynikami w skali e-zdrowia. }\end{array}$ \\
\hline 3. & $\begin{array}{c}\text { Jordan S., } \\
\text { (et al.), 2016. } \\
\text { Niemcy [19] }\end{array}$ & $\begin{array}{l}\text { Ocena kompetencji } \\
\text { zdrowotnych wśród } \\
\text { społeczeństwa Niemiec. }\end{array}$ & $\begin{array}{c}n=4952 \text { osoby w wieku } \\
\geq 18 \text { lat }\end{array}$ & $\begin{array}{c}\text { Sondaż diagnostyczny/ } \\
\text { Kwestionariusz HLS-EU-Q16; } \\
\text { Autorski Kwestionariusz } \\
\text { ankiety }\end{array}$ & $\begin{array}{l}\text { Rozkład w grupie: Ponad połowa dorosłych (55,8\%) } \\
\text { ma wystarczający, } 31,9 \% \text { problematyczny a } 12,3 \% \\
\text { nieadekwatny poziom Health Literacy. } \\
\text { Zalezności i związki: Wykształcenie, wiek oraz stan zdrowia } \\
\text { psychicznego znaczacco wiązały się z poziomem Health Literacy. } \\
\text { Natomiast płećnnie wpływała znacząco na jego poziom. }\end{array}$ \\
\hline 4. & $\begin{array}{l}\text { Levin-Zamir } \\
\text { D., (et al.), } \\
2016 . \\
\text { Izrael [13] }\end{array}$ & \begin{tabular}{|c|} 
Zbadanie związku \\
między umiejętnościami \\
zdrowotnymi, zachowaniami \\
zdrowotnymi, wskaźnikami \\
socjodemograficznymi i \\
samooceną zdrowia \\
w populacji dorosłych osób \\
w lzraelu. \\
\end{tabular} & $\begin{array}{c}\mathrm{n}=600 \text { osób w wieku } \\
\quad \geq 18 \text { lat }\end{array}$ & $\begin{array}{c}\text { Sondaż diagnostyczny/ } \\
\text { Kwestionariusz HLS-EU-Q16; } \\
\text { Autorski Kwestionariusz } \\
\text { ankiety }\end{array}$ & $\begin{array}{c}\text { Rozkład w grupie: Ponad 31\% badanych miała } \\
\text { niewystarczające lub problematyczne umiejętności } \\
\text { zdrowotne, a } 69 \% \text { wykazywało wystarczającą wiedzę na } \\
\text { temat zdrowia. } \\
\text { Zależności i związki: Na poziom Health Literacy wpływa } \\
\text { wiek, wykształcenie oraz dochód osoby badanej. }\end{array}$ \\
\hline 5. & $\begin{array}{c}\text { Almaleh R., } \\
\text { (et al.), 2017, } \\
\text { Egipt [20] }\end{array}$ & $\begin{array}{c}\text { Pomiar umiejętności } \\
\text { zdrowotnych i zbadanie } \\
\text { czynników związanych z } \\
\text { nieodpowiednim poziomem } \\
\text { Health Literacy. }\end{array}$ & $\begin{array}{l}\mathrm{n}=805 \text { pacjentów } \\
\text { poradni ambulatoryjnej } \\
\text { Uniwersyteckiego } \\
\text { Szpitala EL-Demerdash, } \\
\text { w wieku 15-85 lat }\end{array}$ & $\begin{array}{c}\text { Sondaż diagnostyczny/ } \\
\text { Kwestionariusz HLS-EU-016; } \\
\text { Skala umiejętności } \\
\text { funkcjonalnych (S-FHL scale) }\end{array}$ & \begin{tabular}{|c|} 
Rozkład w grupie: $81 \%$ badanych miało ograniczoną \\
wiedzę na temat zdrowia; $34,3 \%$ niewystarczająca; $46,7 \%$ \\
problematyczną, a tylko $18,9 \%$ miało wystarczający poziom \\
Health Literacy. \\
Zależności i związki: Mężczyźni, osoby o niskim poziomie \\
wykształcenia oraz pacjenci o niskim poziomie sprawności \\
funkcjonalnej byli bardziej narażeni na niewystarczający \\
poziom Health Literacy.
\end{tabular} \\
\hline \multicolumn{6}{|c|}{ Health Literacy wśród osób starszych } \\
\hline 6. & $\begin{array}{c}\text { Eronen J. } \\
\text { (et al.), 2018. } \\
\text { Finlandia [21] }\end{array}$ & $\begin{array}{c}\text { Ocena Health Literacy wśród } \\
\text { osób starszych. }\end{array}$ & $\begin{array}{c}\mathrm{n}=292 \text { osoby w wieku } \\
75 \text { lat }\end{array}$ & $\begin{array}{c}\text { Sondaż diagnostyczny/ } \\
\text { Kwestionariusz HLS-EU-016; } \\
\text { Autorski Kwestionariusz } \\
\text { ankiety }\end{array}$ & $\begin{array}{c}\text { Rozkład w grupie: 4,8\% uczestników miało } \\
\text { niewystarczający, 31,5\% problematyczny, 51,4\% } \\
\text { dostateczny a 12,3\% znakomity poziom Health Literacy. } \\
\text { Zależności i związki: Lepsza znajomoś́ zdrowia wiązała } \\
\text { się z lepszym stanem poznawczym, mniejszą liczbą } \\
\text { objawów depresyjnych i chorób przewlekłych, większą } \\
\text { mobilnością i lepszym stanem fizycznym. }\end{array}$ \\
\hline 7. & $\begin{array}{c}\text { Tiller D., } \\
\text { (et al.), 2015. } \\
\text { Niemcy [22] }\end{array}$ & $\begin{array}{l}\text { Określenie poziomu Health } \\
\text { Literacy wśród osób } \\
\text { starszych. }\end{array}$ & $\begin{array}{l}\mathrm{n}=1117 \text { osób w wieku } \\
55-91 \text { lat }\end{array}$ & $\begin{array}{c}\text { Sondaż diagnostyczny/ } \\
\text { Kwestionariusz HLS-EU-Q16 }\end{array}$ & $\begin{array}{l}\text { Rozkład w grupie: Spośród wszystkich badanych 4\% } \\
\text { wykazało niedostateczna, } 23 \% \text { problematyczna, } 50 \% \\
\text { wystarczającą i 23\% doskonałą wiedzę w zakresie Health } \\
\text { Literacy. } \\
\text { Zależności i związki: Na poziom Health Literacy } \\
\text { pozytywnie wpływa wyższy poziom wykształcenia, status } \\
\text { materialny oraz wyższa samoocena pozycji społecznej. } \\
\text { Wykazano również wzrost kompetencji zdrowotnych wraz } \\
\text { z wiekiem badanych osób. }\end{array}$ \\
\hline \multicolumn{6}{|c|}{ Health Literacy wśród osób z różnym stopniem wykształcenia } \\
\hline 8. & $\begin{array}{c}\text { ReickS., } \\
\text { (et al.), 2018. } \\
\text { Niemcy [23] }\end{array}$ & $\begin{array}{l}\text { Ocena kompetencji } \\
\text { zdrowotnych wśród } \\
\text { studentów. }\end{array}$ & $\begin{array}{l}n=203 \text { studentów } \\
\text { w wieku } \geq 19 \text { lat }\end{array}$ & $\begin{array}{l}\text { Sondaż diagnostyczny/ } \\
\text { Kwestionariusz HLS-EU-016 }\end{array}$ & $\begin{array}{c}\text { Rozkład w grupie: } 30,7 \% \text { studentów ma wystarczającą } \\
\text { lub doskonałą znajomość zdrowia. } \\
\text { Zależności i związki: Lepszy poziom kompetencji } \\
\text { zdrowotnych stwierdzono u studentów kierunków } \\
\text { medycznych. }\end{array}$ \\
\hline 9. & $\begin{array}{c}\text { Storms H., } \\
\text { (et al.), } 2017 . \\
\text { Belgia [24] }\end{array}$ & $\begin{array}{c}\text { Zbadanie wykonalności HLS- } \\
\text { EU-016 w populacji ludzi } \\
\text { z małą umiejętnością } \\
\text { czytania i pisania. }\end{array}$ & $\begin{array}{l}\text { n=13 osób w wieku } \\
\text { 18-70 lat, } \mathrm{z} \text { niskim } \\
\text { wykształceniem } \\
\text { i dochodem }\end{array}$ & $\begin{array}{l}\text { Sondaż diagnostyczny/ } \\
\text { Kwestionariusz HLS-EU-Q16 }\end{array}$ & $\begin{array}{l}\text { Pytania dotyczące „zapobiegania chorobom” lub „,oceny } \\
\text { informacji” były często zgłaszane jako niezrozumiałe. HLS- } \\
\text { EU-Q16 jest odpowiednim instrumentem do określania HL } \\
\text { u osób z ograniczoną umiejętnością czytania i pisania. Jednak, } \\
\text { aby ułatwić zastosowanie i interpretację narzędzia, niektóre } \\
\text { pytania należałoby uprościć lub dołączyć wyjaśnienia. }\end{array}$ \\
\hline
\end{tabular}




\section{Health Literacy - a review of research using the European Health Literacy Questionnaire (HLS-EU-Q16) in 2010-2018}

Tab. 1 cd. Zakres i charakter badań dotyczących kompetencji zdrowotnych (Health Literacy) z wykorzystaniem Europejkkiego Kwestionariusza Kompetencji Zdrowotnych (HLS-EU-Q16)

\begin{tabular}{|c|c|c|c|c|c|}
\hline Lp. & Autorzy & Cel pracy & Liczba badanych & \begin{tabular}{|c|}
$\begin{array}{c}\text { Metoda/Narzędzie } \\
\text { badawcze }\end{array}$ \\
\end{tabular} & Główne wyniki badań \\
\hline \multicolumn{6}{|c|}{ Health Literacy wśród uchodźców i więźniów } \\
\hline 10. & $\begin{array}{c}\text { Abellan C., } \\
\text { (et al.), 2018. } \\
\text { Szwajcaria } \\
{[25]} \\
\end{array}$ & $\begin{array}{l}\text { Określenie poziomu Health } \\
\text { Literacy więźniów } \\
\text { w kantonie Vaud. }\end{array}$ & n=50 więźniów & $\begin{array}{l}\text { Sondaż diagnostyczny/ } \\
\text { Kwestionariusz HLS-EU-016 }\end{array}$ & $\begin{array}{l}\text { Rozkład w grupie: } 38 \% \text { badanych osób miało } \\
\text { nieodpowiedni poziom Health Literacy. }\end{array}$ \\
\hline 11. & $\begin{array}{c}\text { Gele A. A., } \\
\text { (et al.), 2016. } \\
\text { Oslo [11] }\end{array}$ & $\begin{array}{l}\text { Ocena poziomu Health } \\
\text { Literacy wśród somalijskich } \\
\text { imigrantek w 0slo }\end{array}$ & $\begin{array}{c}\mathrm{n}=302 \text { somalijskich } \\
\text { kobiet } \mathrm{w} \text { wieku } \geq 25 \text { lat }\end{array}$ & $\begin{array}{c}\text { Sondaż diagnostyczny/ } \\
\text { Kwestionariusz HLS-EU-Q16; } \\
\text { Autorski Kwestionariusz } \\
\text { ankiety }\end{array}$ & $\begin{array}{l}\text { Rozkład w grupie: } 41,8 \% \text { uczestniczek badania miało } \\
\text { niewystarczającą lub problematyczną ogólną wiedzę } \\
\text { na temat zdrowia. Tylko 28\% badanej próby miało } \\
\text { wystarczający lub doskonały poziom Health Literacy. } \\
\text { Zależności i związki: Kobiety bezrobotne i słabo } \\
\text { wykszzałcone miały niższy poziom Health Literacy. }\end{array}$ \\
\hline 12. & $\begin{array}{l}\text { Wangdahl J., } \\
\text { (et al.), 2018. } \\
\text { Szwecja [12] }\end{array}$ & $\begin{array}{l}\text { Zbadanie kompetencji } \\
\text { zdrowotnych wśród } \\
\text { uchodźców w Szwecji. }\end{array}$ & $\begin{array}{c}\mathrm{n}=513 \text { uchodźców } \\
\text { mówiących po arabsku, } \\
\text { dari i somalijsku w } \\
\text { wieku } \geq 18 \text { lat }\end{array}$ & $\begin{array}{c}\text { Sondaż diagnostyczny/ } \\
\text { Kwestionariusz HLS-EU-016 } \\
\text { Autorski Kwestionariusz } \\
\text { Ankiety }\end{array}$ & $\begin{array}{c}\text { Rozkład w grupie: } 67 \% \text { badanych miało nieadekwatny } \\
\text { lub problematyczny poziom Health Literacy. } 41 \% \text { badanych } \\
\text { oceniło swój stan zdrowia jako przeciętny. } \\
\text { Zależności i związki: Osoby z gorszą samooceną własnego } \\
\text { stanu zdrowia mają znacząco niższy poziom kompetencji } \\
\text { zdrowotnych. }\end{array}$ \\
\hline \multicolumn{6}{|c|}{ Health literacy wśród osób z wybraną jednostką chorobową } \\
\hline 13. & $\begin{array}{l}\text { Diederichs C., } \\
\text { (et al.), 2018. } \\
\text { Niemcy [10] }\end{array}$ & $\begin{array}{l}\text { Ocena Health Literacy } \\
\text { u kobiet i mężczyzn } \\
\text { z chorobą sercowo- } \\
\text { naczyniową. }\end{array}$ & $\begin{array}{c}\mathrm{n}=13577 \text { osób w wieku } \\
\geq 40 \text { lat }\end{array}$ & $\begin{array}{c}\text { Sondaż diagnostyczny/ } \\
\text { Kwestionariusz HLS-EU-Q16 }\end{array}$ & $\begin{array}{c}\text { Rozkład w grupie: Problematyczny poziom kompetencji } \\
\text { zdrowotnych wykazało } 41,8 \% \text { mężzzyzn oraz } 46,7 \% \text { kobiet } \\
\text { z chorobą sercowo-naczyniową oraz 33,6\% mężczyzn i 33,4 } \\
\text { kobiet bez choroby. } \\
\text { Zależności i związki: Niski poziom Health Literacy } \\
\text { towarzyszył częściej osobom z chorobami sercowo- } \\
\text { naczyniowymi. }\end{array}$ \\
\hline 14. & \begin{tabular}{|c|} 
Halbach S. M., \\
(et al.), 2016. \\
Niemcy [26]
\end{tabular} & $\begin{array}{l}\text { Określenie poziomu Health } \\
\text { Literacy wśród kobiet ze } \\
\text { świeżo zdiagnozowanym } \\
\text { rakiem piersi. }\end{array}$ & $\begin{array}{l}n=1359 \text { pacjentek } \\
\text { w wieku } \geq 65 \text { lat }\end{array}$ & $\begin{array}{c}\text { Sondaż diagnostyczny/ } \\
\text { Kwestionariusz HLS-EU-016; } \\
\text { Kwestionariusz lęku przed } \\
\text { progresją raka (FoP-0) }\end{array}$ & $\begin{array}{c}\text { Rozkład w grupie: } 47 \% \text { pacjentek posiadało ograniczony } \\
\text { poziom Health Literacy. } \\
\text { Zależności i związki: Kobiety z większym poziomem } \\
\text { lęku przed progresją raka miały niższy poziom kompetencji } \\
\text { zdrowotnych. } \\
\end{array}$ \\
\hline 15. & $\begin{array}{c}\text { Juul L., } \\
\text { (et al.), 2018. } \\
\text { Dania [27] }\end{array}$ & $\begin{array}{c}\text { Zbadanie związków między } \\
\text { poziomem Health Literacy } \\
\text { a dietą i aktywnością } \\
\text { fizyczną, oraz motywacją } \\
\text { u osób z cukrzycą typu 2. }\end{array}$ & $\begin{array}{c}\text { n=194 osoby z cukrzyca } \\
\text { typu II. Średnia wieku } \\
65 \text { lat }( \pm 10)\end{array}$ & $\begin{array}{c}\text { Sondaż diagnostyczny/ } \\
\text { Kwestionariusz pomiaru } \\
\text { czynności związanych } \\
\text { z samoobsługą w cukrzycy } \\
\text { (SDSCA); } \\
\text { Skala samoregulacji } \\
\text { leczenia w cukrzycy (TSRQ); } \\
\text { Kwestionariusz HLS-EU-016; }\end{array}$ & $\begin{array}{c}\text { Rozkład w grupie: } 11 \% \text { badanych osób miało } \\
\text { niewystarczający, } 27 \% \text { problematyczny, a } 63 \% \\
\text { wystarczający poziom Health Literacy. } \\
\text { Zależności i związki: 0soby z wyższym poziomem Health } \\
\text { Literacy mają lepszą motywację do przestrzegania zaleceń } \\
\text { żywieniowych i aktywności fizycznej. }\end{array}$ \\
\hline \multicolumn{6}{|c|}{ Ocena właściwości psychometrycznych Kwestionariusza HLS-EU-Q16 } \\
\hline 16. & $\begin{array}{c}\text { Nolasco A., } \\
\text { (et al.), 2018. } \\
\text { Hiszpania } \\
\text { [14] }\end{array}$ & \begin{tabular}{|c|} 
Ocena zrozumienia \\
oraz właściwości \\
psychometrycznych \\
kwestionariusza HLS-EU-016
\end{tabular} & $\begin{array}{c}\mathrm{n}=5485 \text { osób w wieku } \\
\geq 15 \text { lat }\end{array}$ & $\begin{array}{l}\text { Sondaż diagnostyczny/ } \\
\text { Kwestionariusz HLS-EU-016 }\end{array}$ & \begin{tabular}{|} 
W badaniu uzyskano wysokie wartości zrozumienia \\
stwierdzeń zawartych w kwestionariuszu przez \\
respondentów. Alfa Cronbacha wyniósł 0,982. \\
Współczynnik zrozumienia kwestionariusza wiązał się \\
z wykształceniem badanych osób. \\
\end{tabular} \\
\hline 17. & $\begin{array}{c}\text { Rouquette A., } \\
\text { (et al.), 2018. } \\
\text { Francja [15] }\end{array}$ & $\begin{array}{l}\text { Walidacja Kwestionariusza } \\
\text { HLS-EU-016. Ocena } \\
\text { wpływu płci, wieku oraz } \\
\text { wykształcenia na poziom } \\
\text { kompetencji zdrowotnych. }\end{array}$ & $\begin{array}{c}\mathrm{n}=317 \text { pacjentów } \mathrm{POZ} \\
\mathrm{w} \text { wieku } \geq 18 \text { lat }\end{array}$ & $\begin{array}{l}\text { Sondaż diagnostyczny/ } \\
\text { Kwestionariusz HLS-EU-016 }\end{array}$ & $\begin{array}{c}\text { Zdaniem autorów HLS-EU-016 ma akceptowalne } \\
\text { właściwości psychometryczne. Jego użycie zalecane jest do } \\
\text { pomiaru Health Literacy w populacjach z wystarczającymi } \\
\text { umiejętnościami czytania, aby odróżniać osoby z niskim od } \\
\text { średniego Health Literacy. } \\
\text { Rozkład w grupie: } 8 \% \text { badanych miało nieodpowiedni, } \\
33 \% \text { problematyczny, } 58 \% \text { odpowiedni poziom Health } \\
\text { Literacy. } \\
\text { Zależności i związki: Wykazano, że płeć, wiek oraz } \\
\text { wykształcenia wpływają na zakres posiadanych kompetencji } \\
\text { zdrowotnych. }\end{array}$ \\
\hline
\end{tabular}


stan poznawczy i fizyczny badanych osób, występowanie choroby przewlekłej [21] a także poziom wykształcenia, pozycja społeczna oraz status materialny [22]. W badaniach jednego $\mathrm{z}$ autorów wykazano wzrost poziomu kompetencji zdrowotnych wraz $\mathrm{z}$ wiekiem badanych osób [22].

Badania prowadzono także w grupie osób $\mathrm{z}$ różnym poziomem wykształcenia $[23,24]$. Według wyników badania przeprowadzonego na grupie studentów różnych kierunków studiów wynika, że prawie 31\% ogólnej liczby studentów ma wystarczającą lub doskonałą znajomość zdrowia. Lepszy poziom Health Literacy mają studenci kierunków medycznych [23]. Jeden z autorów badał wykonalność Kwestionariusza HLS-EU-Q16 wśród osób $\mathrm{z}$ niskim poziomem wykształcenia [24]. Wykazano, że HLS-EU-Q16 jest odpowiednim instrumentem do określania Health Literacy u osób z ograniczoną umiejętnością czytania i pisania. Jednak, aby ułatwić zastosowanie i interpretację narzędzia, według autora niektóre pytania należałoby uprościć lub dołączyć wyjaśnienia.

Zainteresowaniem badaczy cieszyło się również określenie poziomu Health Literacy uchodźców i imigrantów $[11,12]$ oraz więźniów [25]. W analizowanych badaniach, blisko $42 \%$ imigrantek miało niewystarczający lub problematyczny poziom Health Literacy [11]. Natomiast wśród grupy uchodźców aż 67\% miało nieadekwatny lub problematyczny poziom Health Literacy [12]. Na poziom kompetencji zdrowotnych wśród tej grupy decydujący wpływ miało bezrobocie, poziom wykształcenia [11] oraz niska samoocena własnego zdrowia [12]. W badaniach przeprowadzonych na więźniach, 38\% badanych miało nieodpowiedni poziom Health Literacy [25].

Autorzy badali również poziom kompetencji zdrowotnych wśród osób z wybraną jednostką chorobową tj. z chorobą sercowo-naczyniową [10], z rakiem piersi [26], oraz z cukrzycą typu 2 [27]. Wyniki badań prowadzone w grupie chorych przewlekle wskazują, że mają oni niższy ogólny poziom kompetencji zdrowotnych niż osoby zdrowe [10]. Dodatkowo poziom Health Literacy wiąże się ze stopniem zaawansowania choroby u tych osób. W przypadku kobiet chorych na raka piersi, respondentki charakteryzujące się niskim poziomem Health Literacy, wykazywały wysoki poziom lęku przed progresją choroby [26]. Zaś w przypadku chorych na cukrzycę typu 2, osoby mające wysoki poziom Health Literacy równocześnie wykazywały się większą motywacją do przestrzegania zaleceń żywieniowych i aktywności fizycznej [27].

Wśród analizowanych artykułów znalazły się i te, które miały na celu określenie właściwości psychometrycznych Kwestionariusza HLS-EU-Q16 [14,15]. Wykazano, że kwestionariusz jest odpowiednim narzędziem do oceny kompetencji zdrowotnych wśród osób z wystarczającymi umiejętnościami pisania i czytania. Stwierdzenia zawarte w kwestionariuszu były zrozumiałe przez respondentów, zaś współczynnik rzetelności narzędzia uklasyfikował się na wysokim poziomie (Alfa Cronbacha > 0,982) [14].

\section{DYSKUSJA}

W niniejszym artykule został przedstawiony przegląd piśmiennictwa $\mathrm{z}$ wykorzystaniem Kwestionariusza HLS-EU-Q16 z lat 2010 - 2018. Wybrano artykuły z tego przedziału czasowego gdyż jest to okres w którym badania kompetencji zdrowotnych nabywają coraz większego znaczenia dla zdrowia publicznego i opieki zdrowotnej na całym świecie. Zagadnieniem kompetencji zdrowotnych zaczęto interesować się już pod koniec XX wieku, natomiast szeroki rozwój badań na ten temat nastąpił po 2010 roku, kiedy to Sorensen i wsp. [7] przeprowadzili Europejskie badanie dotyczące kompetencji zdrowotnych wśród wybranych krajów europejskich. Celem projektu było ugruntowanie pozycji kompetencji zdrowotnych w Europie, poprzez przyczynienie się do dalszego rozwoju pojęcia „kompetencje zdrowotne”, ukazanie jego przejawów w różnych regionach i kulturach europejskich oraz omówienie jego wpływu w wymiarze społecznym i politycznym, a także udokumentowanie jak idea Health Literacy jest wdrażana w różnych krajowych kontekstach [28].

Badania HLS-EU wywołały ogromne zainteresowanie nie tylko w Europie ale i na świecie. Odzwierciedlenie tej tezy znajduje się w analizowanym materiale, gdzie oprócz badań prowadzonych w Europie znajdują się też prace pochodzące $z$ innych zakątków świata takich jak Ghana (Afryka) [17], Izrael (Azja) [13] czy Egipt [20]. Autorzy skupili się na ocenie poziomu Health Literacy wśród wymienionych społeczeństw oraz określeniu czynników związanych z poziomem kompetencji zdrowotnych w tych krajach. Najniższy poziom Health Literacy reprezentowali mieszkańcy Ghany, gdzie blisko 63\% badanych miało problematyczny lub niewystarczający poziom Health Literacy. Niski poziom Health Literacy występował częściej $\mathrm{u}$ afrykańskich kobiet oraz wiązał się ze statusem materialnym badanych osób. Taka sytuacja zdaniem Amoah i wsp. spowodowana była złą sytuacją ekonomiczną państwa, ograniczonymi możliwościami kształcenia wśród społeczności Ghany oraz patriarchalną strukturą społeczną, przedkładającą potrzeby mężczyzn nad potrzeby kobiet [17]. Podobne wyniki uzyskał Levin Zamir, badając społeczność Izraela [13]. Nieco inne czynniki kształtujące poziom kompetencji zdrowotnych przedstawia Almaleh i wsp. [20]. W badaniach tych autorów, przeprowadzonych na pacjentach poradni ambulatoryjnej w Egipcie, wynika ze największym czynnikiem kształtującym Health Literacy jest płeć (mężczyźni mają niższe Health Literacy niż kobiety), sprawność funkcjonalna oraz poziom wykształcenia [20]. W badaniach europejskich zauważalny był wyższy ogólny poziom Health Literacy niż w badaniach pozaeuropejskich. Jordan i wsp. [19] przeprowadzając badania wśród społeczności Niemiec nie odnotował znaczącego wpływu rodzaju płci na poziom Health Literacy. Zdaniem autora najbardziej istotnymi determinantami określającymi kompetencje zdrowotne są wykształcenie, wiek, oraz stan zdrowia psychicznego. W jego badaniach ponad połowa badanych osób $(55,8 \%)$ miała wystarczający poziom Health Literacy [19]. Doszukując się przyczyn dysproporcji w poziomach Health Literacy w wynikach badań z krajów europejskich i pozaeuropejskich można 
wymienić lepsze ugruntowanie projektów dotyczących rozwoju i nabywania kompetencji zdrowotnych w Europie niż w innych częściach świata. Wyniki HLS-EU stały się podstawą do powstania wielu międzynarodowych dokumentów i zapisów strategicznych dotyczących Health Litearcy w dokumentach m.in. Parlamentu Europejskiego i Unii Europejskiej. Ma to na celu ciągłe pogłębienie wiedzy na temat zdrowia i uczynienie zagadnienia Health Literacy priorytetem w polityce europejskiej. W tym celu opracowano i rozpowszechniono obszerny artykuł wśród grup interesu działających w społeczności Unii Europejskiej, zatytułowany Sprawić, aby wiedza o zdrowiu była priorytetem $w$ polityce UE ( $\mathrm{z}$ ang. Making health literacy a priority in EU policy) [29].

Umiejętności zdrowotne są również bardzo istotne w przypadku osób starszych. Pozwalają one na zapobieganie niepełnosprawności i zmniejszają zapotrzebowanie na opiekę długoterminową tej grupy. Wpływają one na przebieg procesu samozarządzania chorobą przewlekłą (rozpoznawanie objawów, umiejętność podejmowania działań interwencyjnych w momencie zaostrzenia choroby, stosowanie się do zaleceń lekarskich i wiele innych) [30]. Ograniczone umiejętności zdrowotne powodują pogorszenie stanu funkcjonalnego i umiejętności poznawczych [31]. Ponadto, niski poziom Health Literacy zwiększa ryzyko częstych hospitalizacji w trybie nagłym oraz ryzyko przedwczesnej śmierci [30]. Dlatego tak ważne jest określanie poziomu kompetencji zdrowotnych wśród osób starszych. W dostępnym materiale dwóch autorów [21-22] przeprowadziło badania na osobach w wieku geriatrycznym, przy użyciu HLS-EU-Q16. W badaniach Eronen i wsp. [21] wykazano że lepsza znajomość zdrowia u seniorów, wiązała się z lepszym stanem poznawczym, mniejszą liczbą objawów depresyjnych i chorób przewlekłych, większą mobilnością i lepszym stanem fizycznym.

Światowe trendy migracji i imigracji spowodowały powstanie nowych wyzwań w zakresie świadczenia opieki zdrowotnej z powodu komunikacji, różnic kulturowych i umiejętności zdrowotnych migrantów [32]. To wyjaśnia duże zainteresowanie badaczy określeniem poziomu Health Literacy wśród napływowej ludności. Z analizy dostępnych badań wynika, że poziom Health Literacy u uchodźców i imigrantów jest niższy. Z badań Gele i wsp. [11], którzy ocenili kompetencje zdrowotne wśród somalijskich imigrantek przebywających w Oslo, wynika że decydującym wyznacznikiem niskiego poziomu Health Literacy wśród imigrantów jest bezrobocie oraz niskie wykształcenie. W celu zmniejszenia dysproporcji w zakresie kompetencji zdrowotnych powstało wiele programów promujących Health Literacy wśród migrantów i uchodźców. Przykładem takiej inicjatywy był Tydzień Edukacji Migrantów, organizowany przez Elektroniczną Platformę Kształcenia Dorosłych w Europie (EPALE), działającą w ramach Komisji Europejskiej. Celem tej inicjatywy było podniesienie świadomości na temat kluczowej roli edukacji zdrowotnej w integracji migrantów i uchodźców w całej Europie [33].

Związek pomiędzy Health Literacy a stanem zdrowia jednostki jest niekwestionowany. Uważa się nawet, że niski poziom kompetencji zdrowotnych jest silniejszym wyznacznikiem zdrowia niż wiek, dochód czy poziom wykształcenia. Powyższą tezę potwierdzają doniesienia $\mathrm{z}$ analizowanych badań, przeprowadzonych wśród przewlekle chorych [10,26-27]. Diederichs i wsp. [10] prowadząc badania na osobach $\mathrm{z}$ chorobą sercowo-naczyniową stwierdzili, że niski poziom Health Literacy występuje częściej u chorych kardiologicznie niż u osób zdrowych. Podobne wyniki uzyskali w swych badaniach Juul i wsp. [27]. Stwierdzili oni, że osoby chore na cukrzycę typu II z wyższym poziomem kompetencji zdrowotnych posiadają lepszą motywację do przestrzegania zaleceń żywieniowych i zasad aktywności fizycznej niż osoby z niskim Health Literacy. Zdaniem Mirczak [30] konsekwencją niskiego poziomu kompetencji zdrowotnych wśród osób przewlekle chorych jest deficyt wiedzy na temat posiadanego schorzenia oraz tendencja do negatywnych zachowań zdrowotnych.

W analizowanym materiale nie zabrakło prac oceniających właściwości psychometryczne Kwestionariusza HLS EU Q16 [14-15]. Zdaniem autorów narzędzie ma akceptowalne właściwości psychometryczne. Jego użycie zalecane jest do pomiaru Health Literacy w populacjach z wystarczającymi umiejętnościami czytania, aby odróżniać osoby $\mathrm{z}$ niskim od średniego poziomu kompetencji zdrowotnych [15]. W przypadku osób z małą umiejętnością czytania i pisania dowiedziono że HLS EU Q16 jest odpowiednim instrumentem do określania Health Literacy, jednak, aby ułatwić zastosowanie i interpretację narzędzia, niektóre pytania należałoby uprościć lub dołączyć wyjaśnienia [24]. Kwestionariusz jest krótkim, adekwatnym i ważnym instrumentem do pomiaru poziomu znajomości zagadnień zdrowotnych wśród ludności a jego stosowanie zaleca się do wykrywania potrzeb związanych z zarządzaniem informacjami zdrowotnymi [14].

\section{WNIOSKI}

W dokonanej analizie przeglądu literatury $\mathrm{z}$ wykorzystaniem Kwestionariusza HLS EU Q16 badaniu poddano 31558 osób z 13 krajów. Respondenci znajdowali się w wieku 15-91 lat. Na podstawie analizowanego materiału stwierdzono następujące wnioski.

1. Istnieją wyraźne dysproporcje w poziomie Health Literacy wśród społeczeństw europejskich i pozaeuropejskich.

2. W Europie istnieje wyraźnie lepsze ugruntowanie projektów dotyczących rozwoju i nabywania kompetencji zdrowotnych niż w innych częściach świata.

3. Niższy poziom Health Literacy występuje u osób starszych, osób przewlekle chorych, z niższym wykształceniem oraz wśród imigrantów.

4. Światowe trendy migracyjne przyczyniły się do rozwoju nowych wyzwań w zakresie świadczenia opieki oraz edukacji zdrowotnej napływowej ludności.

5. Kwestionariusz HLS-EU-Q16 jest odpowiednim narzędziem do oceny poziomu Health Literacy wśród różnych populacji. 


\section{Barbara Niedorys, Agnieszka Chrzan-Rodak, Barbara Ślusarska}

\section{REFERENCES/PIŚMIENNICTWO}

1. Nutbeam D. Health Promotion Glossary. Health Promot Int. 1998;13:349-364.

2. Sørensen K, Van den Broucke S, Fullam J, et al. Health literacy and public health: A systematic review and integration of definitions and models. BMC Public Health. 2012; 12:80.

3. Iwanowicz E. "Health Literacy" jako jedno ze współczesnych wyzwań zdrowia publicznego. Medycyna Pracy. 2009;60(5):427-437.

4. Olejniczak D. Praktyczne wykorzystanie health literacy - alfabetyzmu zdrowotnego, jako narzędzia osiągania celów zdrowotnych. Journal of Education, Health and Sport. 2016;6(2):238-243.

5. Karuranga S, Sørensen K, Coleman C, et al. Health Literacy Competencies for European Health Care Personnel. Health Literacy Research and Practice. 2017; 1(4): e247-e256.

6. Sørensen K, Van den Broucke S, Pelikan J, et al. Measuring health literacy in populations: illuminating the design and development process of the European Health Literacy Survey Questionnaire (HLS-EU-Q). BMC Public Health. 2013;13:948.

7. Sørensen $K$, Jurgen M, Pelikan J, et al. Health literacy in Europe: comparative results of the European health literacy survey (HLS-EU). European Journal of Public Health. 2015; 25(6):1053-1058.

8. Doyle G, Cafferkey K. The European health literacy survery. Results from Ireland. UCD Dublin, April 2012.

9. Moher D, Liberati A, Tetzlaff J, et al. Preferred reporting items for systematic reviews and meta-analyses: The PRISMA Statement. PLoS Med. 2009;6(7): e1000097.

10. Diederichs $C$, Jordan $S$, Domanska 0 , et al. Health literacy in men and women with cardiovascular diseases and its association with the use of health care services Results from the population-based GEDA2014/2015-EHIS survey in Germany. PLOS ONE, 6, 2018.

11. Gele A, Pettersen KS, Torheim LE, et al. Health literacy: the missing link in improving the health of Somali immigrant women in 0slo. BMC Public Health. 2016; 16(1):1134.

12. Wangdahl J, Lytsy P, Mírtensson L, Westerling R. Poor health and refraining from seeking healthcare are associated with comprehensive health literacy among refugees: a Swedish crosssectional study. International Journal of Public Health. 2018; 63:409-419.

13. Levin-Zamir D, Baron-Epel 0, Cohen V, Elhayany A. The Association of Health Literacy with Health Behavior, Socioeconomic Indicators, and Self-Assessed Health From a National Adult Survey in Israel. Journal of Health Communication. 2016; 21 : 61-68.

14. Nolasco A, Carmen Baronaa C, Tamayo-Fonsecaa N, el al. Alfabetización en salud: propiedades psicométricasdel cuestionario HLS-EU-016. Gac Sanit. 2018.

15. Rouquette $A$, Nadot $T$, Labitrie $P$, et al. Validity and measurement invariance across sex, age, and education level of the French short versions of the European Health Literacy Survey Questionnaire. PLOS ONE. 2018; 6.

16. Pelikan JM. Developing short forms for the HLS EU Q47 instrument to measure comprehensive Health Literacy in general and specific populations. Dostępny w: https://slideplayer.com/slide/13026267/ [dostęp:06.02.2019r.]

17. Amoah A. Social participation, health literacy, and health and well-being: A crosssectional study in Ghana. SSM - Population Health. 2018; 4: 263-270.

18. Duplaga M, Grysztar M, Tubek A. The association between health literacy and health literacy in young adult population in Poland. European Journal of Public Health 2017; 27(3):432.

19. Jordan S, Hoebel J. Gesundheitskompetenz von Erwachsenen in Deutschland. Ergebnisse der Studie "Gesundheit in Deutschland aktuell" (GEDA). Bundesgesundheitsbl .2015; 58: 942-950.

20. Almaleh R, Helmy $Y$, Farhat $E$, et al. Assessment of health literacy among outpatient clinics attendees at Ain Shams University Hospitals, Egypt: a cross-sectional study. Public Health. 2017;151:137-145.

21. Eronen J, Paakkari L, Erja Portegijs E, et al. Assessment of health literacy among older Finns. Aging Clinical and Experimental Research. 2018; 31: 549-556.

22. Tiller D, Herzog B, Kluttig A, et al. Health literacy in an urban elderly East-German population - results from the population-based CARLA study. BMC Public Health. 2015;15:883.

23. Reick S, Hering $T$, et al. Health literacy of students. Results of an online survey at the Bochum health university (Germany). International Journal of Health Professions. 2018; 5(1): 44-52.

24. Storms H, Claes N, Aertgeerts B, Van den Broucke S. Measuring health literacy among low literate people: an exploratory feasibility study with the HLS-EU questionnaire. BMC Public Health. 2017;17:475.

25. Abellan C, Beaupere P, Bodenmann P. Health literacy: situation of detainees in the canton of Vaud, Switzerland. European Journal of Public Health. 2018; 28(1): STRONY.
26. Halbach SM, Enders A, Kowalski Ch, Pförtner TK, et al. Health literacy and fear of cancer progression in elderly women newly diagnosed with breast cancer A longitudinal analysis. Patient Education and Counseling. 2016; 99: 855-862.

27. Juul L, Gill Rowlandsa G, Terkildsen H, Maindal T. Relationships between health literacy, motivation and diet and physical activity in people with type 2 diabetes participating in peer-led support groups. Primary care diabetes. 2018;12: 331-337.

28. Instytut Kardiologii im. Prymasa Tysiąclecia Stefana Kardynała Wyszyńskiego: Realizacja projektu pt. European Health Literacy Survey (HLS-EU) dostępny w: http://www.ikard.pl/najwazniejsze-osiagniecia-reader/realizacja-projektu-pteuropean-health-literacy-survey-hls-eu.html (dostęp: Czerwiec 2019)

29. Making health literacy a priority in EU policy, Brussels, June 2013, dostępny w: https://docs.wixstatic.com/ugd/76600e_96510d83af174fbab147a7fb30bba079. pdf (dostęp: Czerwiec 2019)

30. Mirczak A. Health literacy level among elderly and chronic disease self-management Journal of Education, Health and Sport. 2017;7(3):72-85.

31. Uemura $\mathrm{K}$, Yamada M, Okamoto H. Effects of Active Learning on Health Literacy and Behavior in Older Adults: A Randomized Controlled Trial. Jurnal American Geriatrics Society. 2018;66:1721-1729.

32. Ward M, Maria Kristiansen M, Sørensen K. Migrant health literacy in the European Union: A systematic literature review. Health Education Journal. 2018; 78(1):81-95.

33. Electronic Platform for Adult Learning in Europe (EPALE): Health literacy and Migrant Education. Dostępny w: https://ec.europa.eu/epale/en/newsletters/ health-literacy-and-migrant-education (dostęp: wrzesień 2019).

Manuscript received/Praca zgłoszona do czasopisma: 11.10.2019

Manuscript accepted/Praca zaakceptowana do druku: 16.12.2019

Translation/Tłumaczenie: Barbara Niedorys 